\title{
岡山県下に発生した流行性肝炎 特に病原体に関する研究
}

\author{
第 二 編 \\ 分離方法を異にして得られた病毒の比較的研究 \\ 岡山大学医学部微生物学数室（主任：村上 栄数授) \\ 真鍋正富 \\ 〔昭和 32 年 6 月 6 日受槁〕
}

\section{緒文}

既《著者は村上等》の流行性肝炎㭧者より

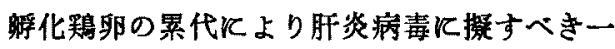
種の病毒を分離した実験に做い，同棣病毒の 分離に成功したが，その後瞹化隠卵反馴化し ない病毒の分離がマウスの累代によつて可能 である事実を知り，更に肝炎の診断法として 応用されている肝䑏穿刺器により切除された

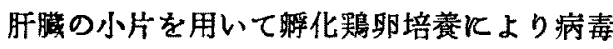
の分離を行い，又患者材料を直接マウスに接 種することにより病毒を分離し，マウスの病 理学的所見により等しい性格をるつ病毒であ る事実を証明した。

著者は第一編に述べた分離材料及び分離方 法を異にして得られた病毒を用い，殊に本編 飞於てはその血清学的性状を Wildführ の “Absättigung8-versuch”を応用して詳細に検 討すると共感染防嗅試験を併用して免疫血 清学的に分離病毒の性状を追究した。

\section{実臨材料及び方法}

供試病毒：第一編で述べた著者の分離した 病毒石原, 小川，青森，野田，佐藤株と肝第 刺片より分離した病毒高取株であり，睬化鶏 卵で累代保存中の石原, 小川株を除き，マウ スの累代で保存されている，之等の病書株は 総てマウスに定型的な病理所見を招来し，而 すとの病理学的变化化現われる性状は一般に 同一の性格を有すると認めている。
交叉的 “Absättigungs-versuch" : Wildführ の原法に倣つたが，術式と判定要領に於ては その㦈を採用出来ないので種々改良を試みた。 即ち動物はマウスを使用し，各種の免疫血清 $0.25 \mathrm{ml}$ 宛 30 分間隔 2 回皮下接種し，体内 そ免疫抗体を移し飽和の状態に達せしめた後, 生病毒を腹膛内に $0.25 \mathrm{ml}$ 㱜接種攻㧘を行 い，病毒接種後 14 日及び 21 日後に於ける病 理所見を観察し中和の程度を判定した。その 夷験方法は殆んど村上等の方法(12)3》飞従つ た.

感染防㸷試験 . 先飞数回試みた ${ }^{2) 33}$ の方法 に做つた。即ち不活化病毒を以て免疫処理し た後稀釈病毒によりて攻慗した，分離病毒夫 々をマウスに接種したる後その肝满を多数 pool したる上，Homogenizer を用いて均等な 病毒含有粗乳刘を作り，Marzonin 10,000 倍の割に添加して氷室に 3 週間保存し不活化 した事を確かめたる後, 多数のマウスに接㮔 免疫を行い（ip $0.25,0.3,0.3 \mathrm{ml} 3$ 回 5 日 間隔), 一定期間後生病毒 $0.3 \mathrm{ml}$ 宛接種攻整 を行つた。 その判定要領は繁ら病理所見に彷 つた.

免疫血清調製 : マウス货度血清の調製は予 め準俌したマウス头々 150２00匹宛分離病 毒乳郕を 3 日間丽 5 回 $\left(10^{-2}\right.$ 稀釈液 $0.2 \mathrm{ml}$, $0.25 \mathrm{ml}, 0.3 \mathrm{ml}, 0.3 \mathrm{ml}, 0.3 \mathrm{ml}$ ) 反復腹腔 内に接楎し最後の注射より 2 週間後探血して 奏験に供した。

癨毒の不活化試験：Marzonin 添加による 
不活化試験は時末の実験飞做い，10,000 倍 (0.01\%) の割飞添加後 1－5週飞互り，マウ スに復原試験を行い，病理学的所見により病 毒の不活化を確かめた，紫外線照射では病毒 稀积液 $10^{-2}$ 浮遊液を直径 $9 \mathrm{~cm}$ のレャーレ内 K $1.0 \mathrm{ml}$ 宛分往し, $10 \mathrm{~cm}$ の距離からマッ 夕紫外線殺菌灯（GL-15 WL）により $100 \mathrm{~V}$, $3 \mathrm{~A}$ そてンャーレを絶えず振鹠を続け $10^{\prime}, 20^{\prime}$, $30^{\prime} ， 40^{\prime}$ と照射を行つた。

\section{実 䣯 成 緓}

1. "Absättigungs-versuch"

Wildführ 恃同氏が初めて行つた “Absättigungs-versuch”を用い肝资病毒間飞型別の存 在することを述べているが，既に村上等によ りても追試せられて括り，Wildführ の原法
は諸種の事情より確認出来なかつたが，用い られる免疫血清の免疫力伍が高い場合は比較 的他の免疫試験の結果と相通ずる所見が得ら れるが，免度力価の低い際には充分に效果を 発揮しないことが実験的に証明されている63

著者は本実験を行う飞当り，実駼使用す る病毒の分離方法飞従つた病毒群の免度血清 を作り実験飞使用した．即ち第 1 群は瞬化鴊 卵型（石原，小川株）と瞬化鵴卵累代保存中 のもの，第 2 群では直接マウスで分離しマウ スで保存中のマウス系 (青森，野田，佐藤株), 肝穿刺片より分離累代中の肝穿刺系(高取株) を第 3 群比分ち夫々の病毒を用いて免疫を行 い血清を得た。 と同時に既知の㤇復患者血清 をす併せて使用した。

実験結果は表示した如くである（第 2 表).

第 1 表 Absättigungs-Versuch

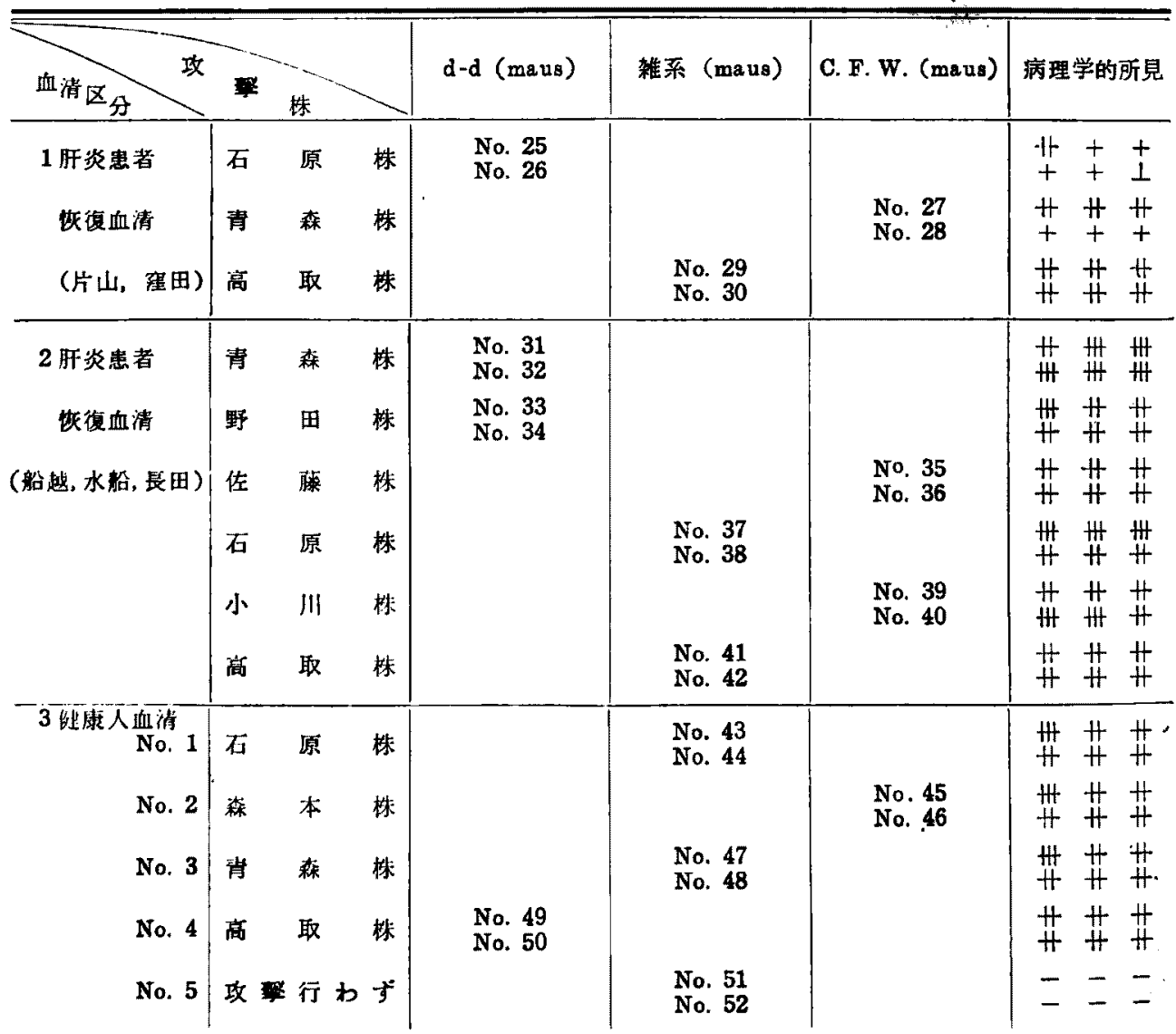

註. i) 病理学的所見中 $(\mathrm{H}) \sim(\perp)$ 病理変化の程度を示す.

ii）州:炎血清中（1）群混合血清陽性，(2)群䧔性（C.f.t.） 
即ち供試血清を肝炎恢復患者に限つた場合， 第 1 群免疫血清反応陽性の血清々免度反応陰 性の第 2 群血清に分ち飽和試験を行つた成績 では，Wildführ の如き確実な所見ではない が，その判定を病理学的所見で行つた結果で は, 第 1 群の方飞於て感染阻止現象が惹起し てょり，第 2 群と於ては感染阻止は明暸でな W.

次に用いた動物別の血清の場合でる，更飞 病毒を異にした群でも，大体中和の傾向は見 られるが，肝穿刺片より得た高取株に於ては 感染阻止は明かでない，この場合の高取株は 分離後累代が浅く，此較的病理変化が不定で ありたまたま斯る病変に遭遇したとも解せら れるるのであり，病毒間任型別が存在するた めの差異とは考兄られない。

な招肝炎恢復患者血清の免疫力価は実験汇 用いた分離病毒による補体結合反応で測定し た際は 1:8〜1:16 程度のものであり量が少 いため混合血清として用いた。次兔度血清 を用いて同様な実験を行つた。既に免度した マウス血清の場合は飽和試駼の結果が信頼し 得られる事実があるが，著者すマウスを免度 しその血清を集めて供試血清とした。 マウス 免疫血清に対して分離病毒別に行つた結果で は，俩毒株により些少の差異はあるが等しく 感染阻止作用のあることが，病理所見飞於て 窥われた。

とれ等の実験で特異的と考えられるのは石 原株免疫血清飞対して，石原株病毒の中和が 明瞭飞進行し，他の病毒株ではやや軽度なが らも病理所見が見られる事実は, 高取株飞よ る中和が明かに発揮されている事类と共に， 飽和試験に於ける中和が特異的に進行してい ることを意味し，更に供試血清の免疫力価の 高い場合が良結果を得るとの証明にすなると 思うのである(第 2 表)．との際用いた免度血 清の補体結合反忘の結果では1：32〜1：64の 陽性結果を得でり，他の中和試験でる中和 現象の惹起することを確かめた血清であっ た.

更に各病毒株間に於ける篎叉試験を行つた。
第 2 表 Absättigungs-Versuch

\begin{tabular}{|c|c|c|c|c|}
\hline & $\begin{array}{l}\text { 權菜 } \\
\text { (Maus) }\end{array}$ & $\begin{array}{l}\text { C. F. W. } \\
\text { (Maus) }\end{array}$ & $\begin{array}{l}\text { 病理学的 } \\
\text { 所 莧 }\end{array}$ \\
\hline 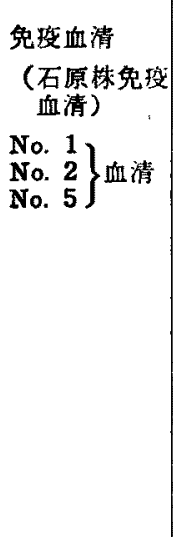 & \begin{tabular}{|l} 
森本株 \\
小川原株 \\
小川株 \\
青森株 \\
野田株 \\
传蔚株 \\
高取株
\end{tabular} & $\begin{array}{l}\text { No. } 13 \\
\text { No. } 14 \\
\text { No. } 17 \\
\text { No. } 18 \\
\\
\text { No. } 19 \\
\text { No. } 20 \\
\\
\\
\text { No. } 23 \\
\text { No. } 24 \\
\text { No. } 25 \\
\text { No. } 26 \\
\text { No. } 27 \\
\text { No. } 28\end{array}$ & $\begin{array}{l}\text { No. } 15 \\
\text { No. } 16 \\
\\
\text { No. } 21 \\
\text { No. } 22\end{array}$ & $\begin{array}{l}\perp \perp+ \\
+++ \\
\perp \perp+ \\
+1++ \\
--- \\
--- \\
+++ \\
+++ \\
\perp+1 \\
\perp \perp+ \\
\perp \perp \perp \\
-\perp+ \\
+++ \\
\perp++ \\
\perp++ \\
\perp++\end{array}$ \\
\hline $\begin{array}{l}\text { 健康血清 } \\
\text { (雑系マウス } \\
\text { 血清) }\end{array}$ & $\begin{array}{l}\text { 金光株 } \\
\text { 石原侏 } \\
\text { 小川怢 } \\
\text { 野田株 } \\
\text { 韋森 } \\
\text { 政 } \\
\text { 行わす }\end{array}$ & $\begin{array}{l}\text { No. } 31 \\
\text { No. } 32 \\
\text { No. } 33 \\
\text { No. } 34 \\
\text { No. } 35 \\
\text { No. } 36 \\
\text { No. } 37 \\
\text { No. } 38 \\
\text { No. } 39 \\
\text { No. } 40\end{array}$ & $\begin{array}{l}\text { No. } 29 \\
\text { No. } 30\end{array}$ & 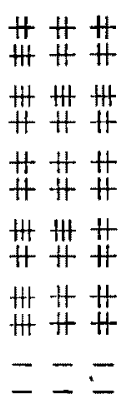 \\
\hline
\end{tabular}

註）i. 病理所見中 $(H) \sim(\perp)$ 病忩の程度を示す。

第 1 群病毒では石原㧣，第 2 群で恃青森株， 第3 群では高取株各血清を用いたが，夫々の 場合によく中和の促進するのが認められ，対 照群と比較し病理所見に軽度でるが定型的 所見に欠げる場合が見られた。

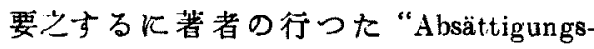
versuch”では肝炎恢復患者血清を供試した時 は納得し得ない結果が稀に見られるのは, 含 まれる免度抗体の量的炕少いためであり，抗 体の含有量の多いと推定される兔浚血清では よく中和現象が観察された。この事実は抗体 の量的関係炕よりその結果が支配されるもの であると考えられ，広義の中和試験がマウス 、体内で行われたるのと解されるのである，分 離方法を哄にした夫ャの分離病毒の間にはそ の性状に大差なく抗原性から見れば明かに一 元性であり，Wildführ の述べたような满毒 
第 3 表 Absättigungs-Versuch

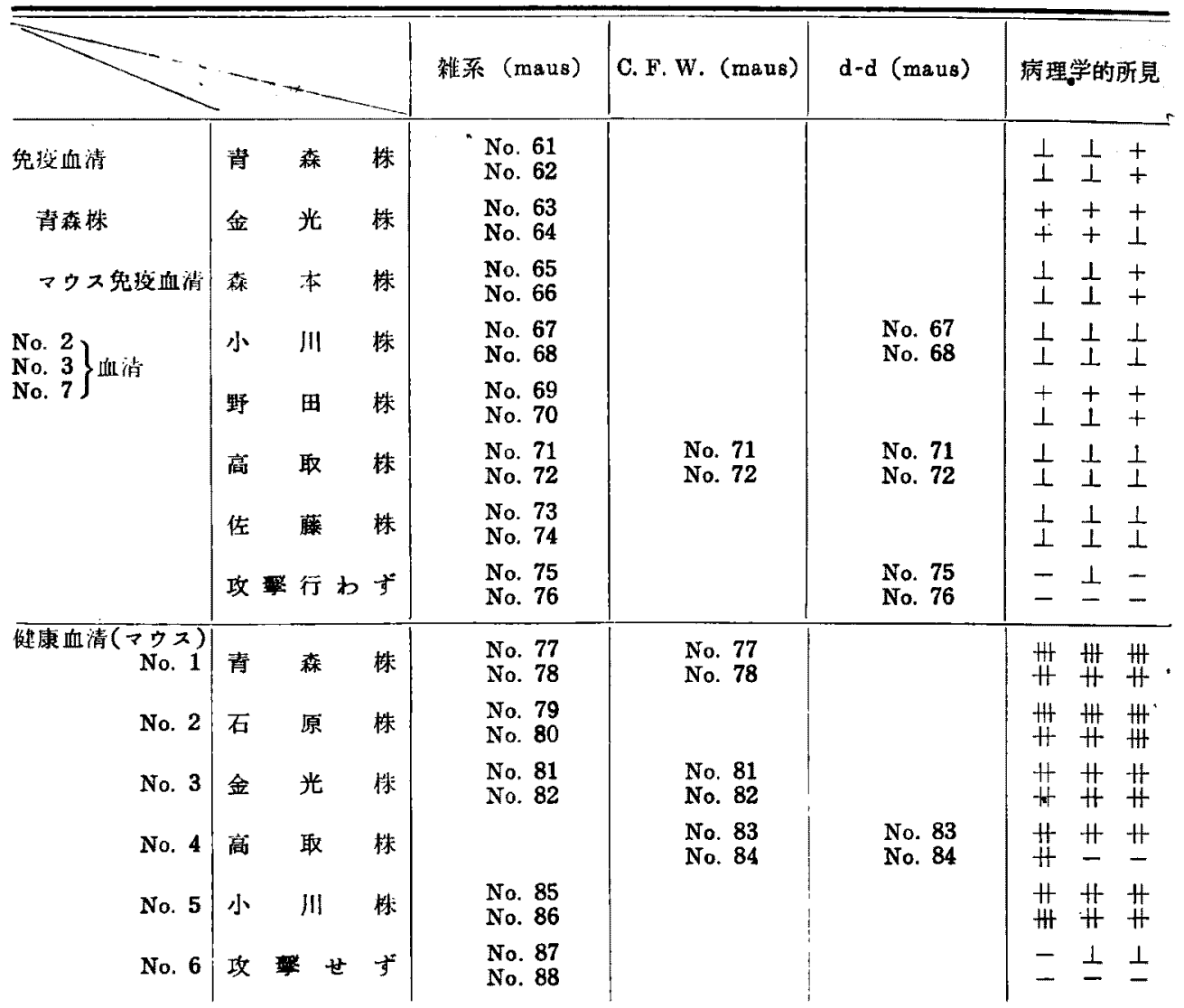

第 4 表 Absättigungs-Versuch

\begin{tabular}{|c|c|c|c|c|c|c|}
\hline \multirow{2}{*}{\multicolumn{2}{|c|}{ 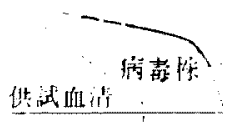 }} & \multirow[b]{2}{*}{$\begin{array}{rr}\text { 雑 } & \text { 系 } \\
(\mathrm{Maus})\end{array}$} & \multirow[b]{2}{*}{$\begin{array}{l}\text { C. F. W. } \\
\text { (Maus) }\end{array}$} & \multicolumn{3}{|c|}{ 病理学的所見 } \\
\hline & & & & 肝满 & 肺跑 & 判定 \\
\hline 先投血消 & 金光株 & $\begin{array}{ll}\text { No. } & 91 \\
\text { No. } & 92\end{array}$ & & $\perp$ & + & $\perp$ \\
\hline 取 株 & 森本珠 & $\begin{array}{l}\text { No. } 93 \\
\text { No. } 94\end{array}$ & $\begin{array}{ll}\text { No. } & 95 \\
\text { No. } & 96\end{array}$ & $\perp$ & + & $\perp$ \\
\hline $\begin{array}{l}\text { アウス免度 } \\
\text { 血清 }\end{array}$ & 小川知 & & $\begin{array}{ll}\text { No. } & 97 \\
\text { No. } & 98\end{array}$ & 1 & + & $\perp$ \\
\hline $\left.\begin{array}{l}\text { No. } 1 \\
\text { No. } 3\end{array}\right\}$ fril & 对原林 & $\begin{array}{lr}\text { No. } & 99 \\
\text { No. } 100\end{array}$ & & $\perp$ & $L$ & $\perp$ \\
\hline & 讨林侎 & & $\begin{array}{l}\text { No. } 101 \\
\text { No. } 102\end{array}$ & + & $\perp$ & + \\
\hline & 野旧侏。 & $\begin{array}{l}\text { No. } 103 \\
\text { No. } 104\end{array}$ & $\begin{array}{l}\text { No. } 105 \\
\text { No. } 106\end{array}$ & 1 & + & + \\
\hline & 份洒件 & $\begin{array}{l}\text { No. } 107 \\
\text { No. } 108\end{array}$ & $\begin{array}{l}\text { No. } 109 \\
\text { No. } 110\end{array}$ & $\perp$ & + & $t$ \\
\hline & 神取侏 & $\begin{array}{l}\text { No. } 111 \\
\text { No. } 112\end{array}$ & $\begin{array}{l}\text { No. } 113 \\
\text { No. } 114\end{array}$ & $\perp$ & + & + \\
\hline
\end{tabular}

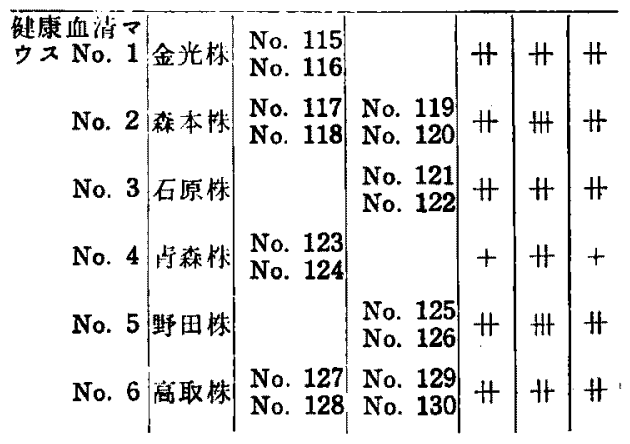

間の型別牥認めることは出来なかつた（第3， 4 表).

分離病毒間飞存する病原性飞は比较的初期

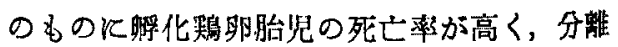
後長期の累代を経たものでは死亡染の低下す る事奏があり、マウスに於てる同様に分離初 期のものでは病理変化の強弱が累代数により 
やや異り，分離後長期累代をした病毒では各 累代於ける病理変化は殆んど同程度の所見 が得ら゙れる等の諸点に鑑み，分離累代数の萿 い青森株更飞高取株飞於ては “Absättigungs. versuch”の成績判定に考虑しなければならな い問題があると考えられる.

\section{2）感染防㵖試験}

感染防禦試験を行 る目的から時末7)の実験飞よる Marzonin 添 加飞よる実験を追試すると共に，紫外線照射 飞よる不活化を試みた。
Marzonin 添加により時末は概ね 3 䓢閒以 上放置することにより病毒の不活化が行われ る事奏を述べたが，藷者の䇛験では新に分離 した高取株を用いた結果，3 週間の保存によ り多んど不活性化され，病理変化は明膫でな いか殆んど晃られないが，多少の細胞浸潤を 認めたに過ぎない例もあつたが，大略 3 週間 以上の保存により不活化が在压行われるもの と判定すへき䋽果であつた。 この罗娩と共に 累代も行い累代 $2 \sim 3$ 代飞於て子確めた結果 判定した (第 5 表).

第 5 表 Marzonin 添加依る病毒の不活性化試験

\begin{tabular}{|c|c|c|c|c|c|c|c|c|c|c|c|}
\hline 理 & \multicolumn{3}{|c|}{ 肝 } & \multicolumn{4}{|c|}{ 渡 } & \multicolumn{2}{|c|}{ 肺 } & \multicolumn{2}{|c|}{ 琏 } \\
\hline 不活化の方法 & 死 & $\begin{array}{l}\text { 肺 } \\
\text { 紏 } \\
\text { 胞 } \\
\text { 変 } \\
\text { 性 }\end{array}$ & $\begin{array}{l}\text { 及星 } \\
\text { 緯 } \\
\text { 增胞 } \\
\text { 腄 } \\
\text { 生大 }\end{array}$ & $\begin{array}{l}\text { 肺 } \\
\text { 索 } \\
\text { の } \\
\text { 解 } \\
\text { 稚 }\end{array}$ & 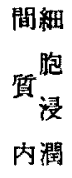 & $\begin{array}{r}\text { 実細 } \\
\text { 質胞 } \\
\text { 内浸 } \\
\text { 内潤 }\end{array}$ & $\begin{array}{l}\text { 充 } \\
\text { 血 } \\
\text { 及 } \\
\text { 出 } \\
\text { 血 }\end{array}$ & $\begin{array}{l}\text { 胞 } \\
\text { 隔 } \\
\text { 炎 }\end{array}$ & 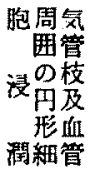 & $\begin{array}{l}\text { 胞 } \\
\text { 隔 } \\
\text { 肥 } \\
\text { 厚 }\end{array}$ & $\begin{array}{l}\text { 出 } \\
\text { 血 }\end{array}$ \\
\hline $\begin{array}{l}\text { Marzonin 添 妿 } \\
(10,000 \text { 倍 }) 1 \text { 週間 }\end{array}$ & $H$ & + & + & + & H & H & + & $H$ & H & + & + \\
\hline $\begin{array}{l}\text { Marzonin } \\
3\end{array}$ & $\perp$ & $\perp$ & $\perp$ & $\perp$ & + & + & $\perp$ & $\perp$ & $\perp$ & + & $\perp$ \\
\hline$\underset{4}{\text { Marzonin }}$ & $\perp$ & $\perp$ & $\perp$ & $\perp$ & + & $\perp$ & $\perp$ & $\perp$ & $\perp$ & $\perp$ & $\perp$ \\
\hline$\underset{5}{\text { Marzonin }}$ & $\perp$ & $\perp$ & $\perp$ & $\perp$ & + & $\perp$ & $\perp$ & $\perp$ & $\perp$ & + & $\perp$ \\
\hline
\end{tabular}

榇. i) Marzonin 添加後氷室保存。

ii) $(H) \sim(\perp)$ 病理变化の程度を示す。

iii）病毒仕高取株.

次に紫外線照射では照射10方では未だ定型 的な病変殊飞肝細胞の変性及び壊死が著明で あり，壤死单周辺に於ける単球の世現が特異 的で，而るマロリ一氏小体る含み，更飞多形 核も少数ながら涩めた事然は特異的な病変で あつた，照射時間を30分に延長する場合は先 述の病理変化が全く見られず，40分に至つて も明かでない点から紫外線照时による不活化 は30〜40分で確笑に行われるるのの如くであ

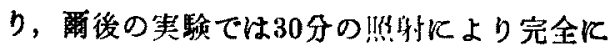
不活化されることを知つたので主に紫外線照 射により不活化病毒を得た（第 6 表）。

紫外線照射を更碓める意味から他の病毒
株に就ても同㥞な方法で同一照射を行つた紹

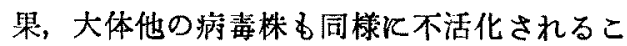
とを病理学的所見の上で知り得た（第 7 济）.

よつて各病表株飞紫外線照射を行い不活化 病素を得，マウスを免疫して齐䡉将青を用い て攻慗する感染交叉允疫奏験を行い，不活化 病青に上る免疫の成立と，抗原性に僦て知り 得た。即ち笕疫の成立する事奏は，不源化病 清を接杼した場合上く生病毒の攻紫に耐過し

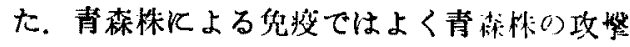

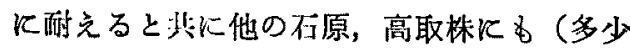
とも病理所見に於ける美界休存するが）耐過 する事実が明かであつた(第 8 表)，次に石原 
第 6 表 紫外線照射飞依る病毒の不活化誠験

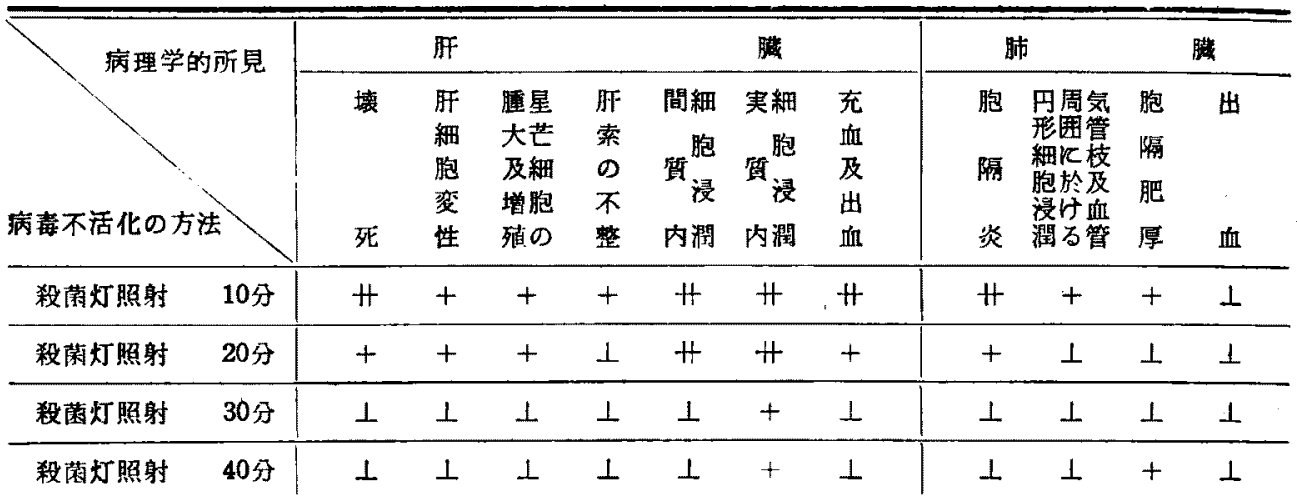

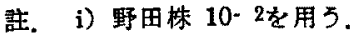

第 7 表 紫外線照射飞依る病毒の不活化試験

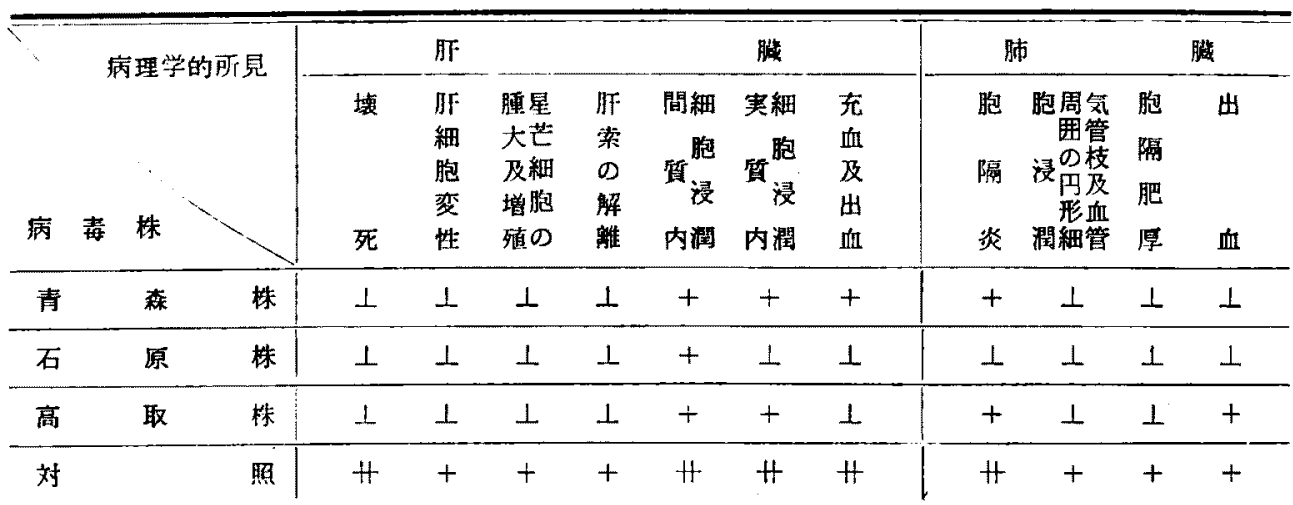

註. i) 紫外線照射夫々 30 分.

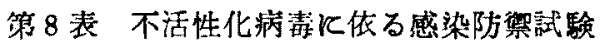

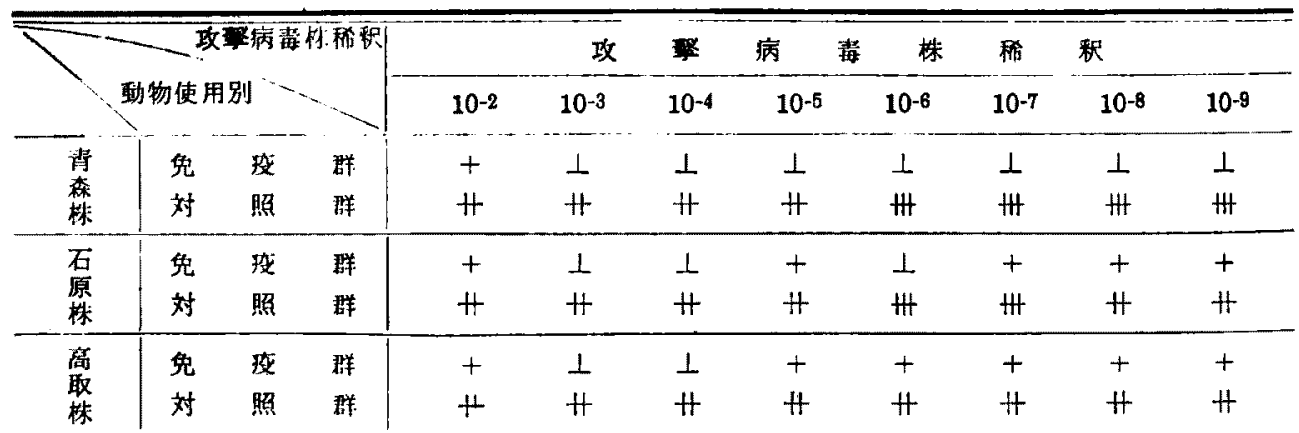

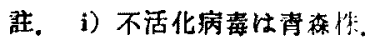

株による不活化病毒の免疫の時も同一生病毒 飞よる攻叙飞耐えると其飞，青森，高取株飞 は軽度の病理変化が認められたに過ぎない (第 9 表).

更に高取株に於ける兔疫でる対照に比較し
て病理所見が著しく軽微であるととは，免疫 性を賦与されたすのと推測される所見である (第10表)。

以上の然験結果では不活化病毒株の接種に より容易にマウスに免疫性を賦与し得るすの 
第 9 表 不活性化病毒飞依る感染防珤試験

\begin{tabular}{|c|c|c|c|c|c|c|c|c|c|c|c|}
\hline \multirow{2}{*}{\multicolumn{4}{|c|}{ 病毒株 }} & \multicolumn{3}{|c|}{ 病 } & \multirow{2}{*}{$\frac{\text { 毒 }}{10-5}$} & \multirow{2}{*}{$\frac{\text { 稀 }}{10-6}$} & \multicolumn{2}{|c|}{ 瀵 } & \multirow[b]{2}{*}{$10-9$} \\
\hline & & & & $10-2$ & $10-3$ & $10^{-4}$ & & & $10^{-7}$ & $10^{-8}$ & \\
\hline 吕 & $\begin{array}{l}\text { 兔 } \\
\text { 対 }\end{array}$ & $\begin{array}{l}\text { 度 } \\
\text { 照 }\end{array}$ & 群 & $\begin{array}{l}\perp \\
\#\end{array}$ & $\frac{1}{H}$ & $\frac{1}{H}$ & $\begin{array}{l}\perp \\
H\end{array}$ & $\stackrel{\perp}{H}$ & $\frac{1}{m}$ & $\perp$ & $\stackrel{\perp}{H}$ \\
\hline $\begin{array}{l}\text { 青 } \\
\text { 森 } \\
\text { 棬 }\end{array}$ & $\begin{array}{l}\text { 免 } \\
\text { 対 }\end{array}$ & $\begin{array}{l}\text { 度 } \\
\text { 照 }\end{array}$ & $\begin{array}{l}\text { 群 } \\
\text { 群 }\end{array}$ & $\begin{array}{l}+ \\
+\end{array}$ & $\frac{1}{H}$ & $\frac{1}{H}$ & $\begin{array}{l}+ \\
H\end{array}$ & $\begin{array}{l}+ \\
H\end{array}$ & $\begin{array}{l}+ \\
+\end{array}$ & $\begin{array}{l}1 \\
+1\end{array}$ & $\begin{array}{l}\perp \\
H\end{array}$ \\
\hline $\begin{array}{l}\text { 高 } \\
\text { 取 } \\
\text { 株 }\end{array}$ & $\begin{array}{l}\text { 免 } \\
\text { 对 }\end{array}$ & $\begin{array}{l}\text { 疫 } \\
\text { 照 }\end{array}$ & $\begin{array}{l}\text { 群 } \\
\text { 群 }\end{array}$ & $\begin{array}{l}+ \\
H\end{array}$ & $\frac{\perp}{H}$ & $\frac{\perp}{H}$ & $\begin{array}{l}\perp \\
H\end{array}$ & $\begin{array}{l}+ \\
+\end{array}$ & $\begin{array}{l}+ \\
+\end{array}$ & $\frac{\perp}{H}$ & $\begin{array}{l}+ \\
+\end{array}$ \\
\hline
\end{tabular}

註。 i) 不活性化病毒的石原株.

第10表 不活性化病毒飞依る感染防繁試験

\begin{tabular}{|c|c|c|c|c|c|c|c|c|c|c|c|}
\hline \multirow{2}{*}{\multicolumn{4}{|c|}{ 病毒使用助物別 }} & \multicolumn{3}{|c|}{ 病 } & 毒 & 釈 & \multicolumn{2}{|c|}{ 稀 } & \multirow[b]{2}{*}{$10-9$} \\
\hline & & & & $10-2$ & $10-3$ & $10-4$ & $10^{-5}$ & $10^{-6}$ & $10-7$ & $10^{-8}$ & \\
\hline $\begin{array}{l}\text { 高 } \\
\text { 取 } \\
\text { 株 }\end{array}$ & $\begin{array}{l}\text { 免 } \\
\text { 対 }\end{array}$ & $\begin{array}{l}\text { 度 } \\
\text { 照 }\end{array}$ & $\begin{array}{l}\text { 群 } \\
\text { 群 }\end{array}$ & $\begin{array}{l}+ \\
+\end{array}$ & $\begin{array}{l}\perp \\
+\end{array}$ & $\begin{array}{l}\perp \\
+\end{array}$ & $\frac{1}{H}$ & $\begin{array}{l}\perp \\
H\end{array}$ & $\begin{array}{l}\perp \\
H\end{array}$ & $\frac{1}{H}$ & $\frac{1}{H}$ \\
\hline $\begin{array}{l}\text { 石 } \\
\text { 愿 }\end{array}$ & $\begin{array}{l}\text { 免 } \\
\text { 対 }\end{array}$ & $\begin{array}{l}\text { 没 } \\
\text { 照 }\end{array}$ & $\begin{array}{l}\text { 群 } \\
\text { 群 }\end{array}$ & $\begin{array}{l}+ \\
H\end{array}$ & $\begin{array}{l}\perp \\
+\end{array}$ & $\frac{\perp}{H}$ & $\frac{1}{H}$ & $\begin{array}{l}+ \\
H\end{array}$ & $\begin{array}{l}+ \\
H\end{array}$ & $\begin{array}{l}+ \\
H\end{array}$ & $\begin{array}{l}+ \\
+\end{array}$ \\
\hline $\begin{array}{l}\text { 青 } \\
\text { 森 } \\
\text { 株 }\end{array}$ & $\begin{array}{l}\text { 免 } \\
\text { 対 }\end{array}$ & $\begin{array}{l}\text { 照 } \\
\text { 照等 }\end{array}$ & $\begin{array}{l}\text { 群 } \\
\text { 群 }\end{array}$ & $\begin{array}{l}+ \\
H\end{array}$ & $\frac{1}{H}$ & $\begin{array}{l}\perp \\
H\end{array}$ & $\begin{array}{l}\perp \\
H\end{array}$ & $\frac{1}{H}$ & $\frac{1}{H}$ & $\begin{array}{l}+ \\
H\end{array}$ & $\begin{array}{l}+ \\
H\end{array}$ \\
\hline
\end{tabular}

註. i) 不活性化病毒俚高取株。

であり，而も他の病毒株で攻慗した場合にも 病理変化の発現をよく阻止する事尖から，供 試病毒間飞於ける抗原性の差は少いるのと推 定される.

次に上記の奏験に使用しなかつた他の病毒
間との関連性を見るに，青森株の不活化病毒 で免疫されたマウスに対して他の生病毒によ る攻整を行う場合，対照群の病理斦見と比較 して抗原性は殆んど等しいものと判定しても よい結果であつた。

第11表 不活化病毒に依る感染防繁試験の主要病理所見

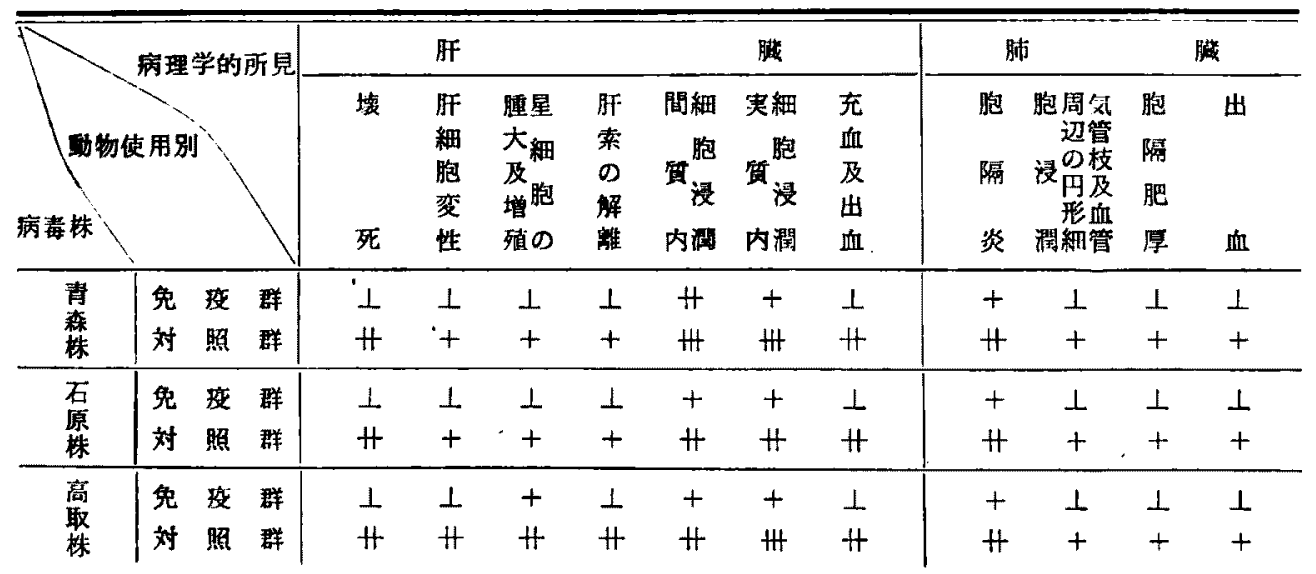

註, i) 病畕怢の不活化以外線照射 30 分.

ii) $($ 州 $\sim(\perp)$ 病変の程度を示す。 
策 12 炡 不活化病毒飞依る感染防禦試験

\begin{tabular}{|c|c|c|c|c|c|c|c|c|c|c|c|}
\hline \multirow{2}{*}{ 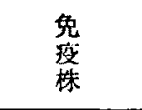 } & \multirow{2}{*}{\multicolumn{3}{|c|}{ 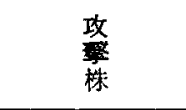 }} & \multicolumn{3}{|c|}{ 病 } & & \multirow{2}{*}{$\frac{\text { 稀 }}{10-6}$} & \multicolumn{2}{|c|}{ 积 } & \multirow[b]{2}{*}{$10^{-9}$} \\
\hline & & & & $10-2$ & $10^{-3}$ & $10-4$ & & & $10-7$ & $10-8$ & \\
\hline \multirow{6}{*}{$\begin{array}{l}\text { 量 } \\
\text { 森 } \\
\text { 奀 } \\
\text { 活 } \\
\text { 华 } \\
\text { 病 } \\
\text { 意 }\end{array}$} & 青 & 森 & 株 & + & $\perp$ & $\perp$ & $\perp$ & $\perp$ & + & + & + \\
\hline & 金 & 光 & 株 & + & 1 & 1 & $\perp$ & $\perp$ & $\perp$ & $\perp$ & $\perp$ \\
\hline & 森 & 本 & 栋 & + & $\perp$ & $\perp$ & $\perp$ & $\perp$ & + & + & + \\
\hline & 小 & III & 株 & $\perp$ & $\perp$ & $\perp$ & $\perp$ & $\perp$ & + & + & + \\
\hline & 野 & 田 & 校 & + & $\perp$ & $\perp$ & $\perp$ & $\perp$ & + & + & + \\
\hline & 佐 & 藤 & 株 & $\perp$ & + & 1 & $\perp$ & $\perp$ & + & + & + \\
\hline $\begin{array}{l}\text { 交免疫行わ照 } \\
\text { 照 }\end{array}$ & 青 & 森 & 株 & $H$ & $H$ & $H$ & $H$ & H & H & $H$ & \# \\
\hline
\end{tabular}

註. i) 不话化は紫外線照射 30 分.

\section{総括及び考按}

肝炎患者から分離した病毒を分離方法別に 血清学的性状を検へ抗原性を筑い，Wildführ の“Absättigungs-versuch”を応用して，更に 感染防禦試験を併用することにより分離病毒 間の血清学的同定を行い，供試病毒間飞抗原 性の差は殆んどないるのと見てよい成績を得 た.

之を詳細に検討するに“Absättigungs-versuch”の効果は血清の先疫打価飞影響を受け， 肝炎恢復患者血清の如き免疫の量的飞低いむ のに対しては一稙の飽和現象は中和の形では 明瞭に発揮されないが，免疫血清に於ては明 瞭に区別されることが少くない，而し全般的 に見て所謂飽和試験単独ではその中和効果は 批判出来るすのではなく，他の\%洪との併用 にまつのが望ましいと推測される。

病毒の不活化は先編に於ては Marzonin 上 りも簡便にしてから效果的な柴外線照射によ つた，本法は長期日を要せす，而电薬品を蒸 加しない利点があり，しかる抗原性を低減 せない点に於て，Marnon より榎れている

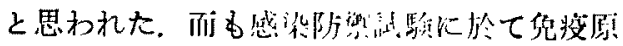
性をよく発推している事招は今终の胙炎に於 けるVaccination に在毕を抱かせるに充分な るのがある。

実䮖結果では不活化将青の接确によりよく

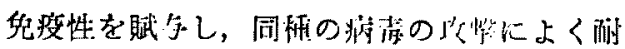

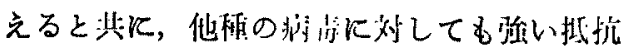

性を発揮する事実が明暸に認められた。

要之するに分離方法を翼にして得られた病 毒間に於ける生物学的及び血清学的性状は概 ね一致した性状を有する。従来記載された病 恝群と明瞭に区別される事実に上り，之等の 病毒が肝炎患者に由来するすのであることは 明かと考觉られる。

\section{結論}

先の第一編に引続き流行性肝炎患者の各種 材料より得られた病毒を用いて免疫血清学的 性状火就て検討した。次の所見を結論として 得た。

1）分離材料及び方法を異にして得られた 各病毒を用いて “Absättigungs-versuch”を行 つた.この飽和試験は Wildführ の原法と多 少その術式及び判定に於て異るが，時に肝炎 患者血清を用いた場合には納得し得ない結果 も少くなかつた，免没価の高い血清ではよく マウス体内に於ける飽和現象による中和が進 行するすのの如く，その病理所見により明瞭 に感染の阻止が発揮されるのが観祭された。

2）病毒の不活化試験では紫外線照射によ る場合が，Marzonin 添加の場合よりも簡単

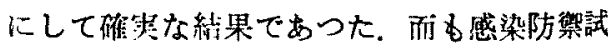
䮖に於ける不活化病毒の允疫效果より推定し てよく抗原性が保有されていた。

3）各種分離病毒の閪飞於ける感染防繁試 跧の結果から判定して，同種の不活化病毒の 先疫に対して同椎の生病毒の攻撃に耐えると 
共に，他種の生病毒の攻撃にもよく耐過する

事実を知り得たと同時に，之等の病毒間には 殆んど抗原性の差は存在しない.

4）以上の成績は肝炎患者の各種材料より 夫々異つた方法で分離し得た病毒が所炎患者

\section{主 要 文 献}

1）村上等：第 2 回ウイルス学会棇会听炎ンンポシ アム, 1955.

2) 村上等: 第 3 回日本ウイルス学会詿谄要旨, 1955.

3）村上等：岡山医学会総会講演要旨， 1955 .

4) 藤原: 未発表.

5) Wildführ, G.: Zeitschr. f. d. Ges. inner. Med. 573, 1953.

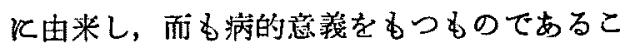
とを強く示唆していると考えられる。

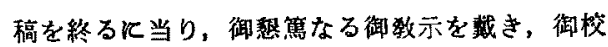

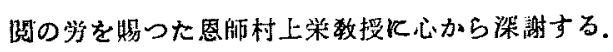

6)村上等：第 4 回ウ1ルス学之総会譄演要昌， 1956.

7) 將末 : 未発表.

8) Havens : J. A. M. A. 134, 653, 1947.

9) Maccallum - Virus and Rickettsial Disieses, 195.

10) Rivers Viral and Rickettsial infection of man, P. 269, 1951.

\title{
Studies on the Pathogenic Agent of Infectious Hepatitis in Okayama Prefecture
}

\section{II : Comparative studies on the viruses isolated from different materials and by different methods}

\author{
By \\ Masatomi Manabe \\ Depatrtment of Microbiology, Okayama University Medical School \\ (Director: Professor Dr. Sakae Murakami)
}

The comparative studies on the viruses isolated from different materials and by different methods were carried out sero-immunologically. The findings are summarized as follows:

1) Using the viruses isolated from different materials and by different methods, the "Absältigunsversuch" was tried. Though the "Absättigungsversuch" was somewhat different from the original wildfüh's method, unacceptable results were sometimes obtained when the sera of hepatilis patients were used. In the mouse the neutraization test was well established between the virus and the immune serum of high titer, and this was proved by the nonappearance of the pathological changes in the mouse.

2) For the inactivation of the virus, ultra-violet irradiation was nore simple and certain than the addition of marzonine. It was proved. 'moreover, that thus inactivated virus still preserved the antigenicity.

3) In the infection-protecting test, the immunization by the inactivated virus protected the attack not only by the same living strain but also by the different strains.

4) These above-mentioned results suggest that the viruses isolated from different materials and by different methods come all from the hepatitis patients and have a pathogenic significance. 